\title{
Geochemistry of the Rare Earth Elements (REE) Distribution in Terengganu Coastal Waters: A Study Case from Redang Island Marine Sediment
}

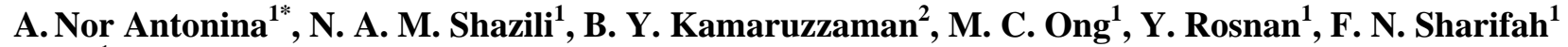 \\ ${ }^{1}$ Department of Marine Science, Faculty of Maritime Studies and Marine Science, University Malaysia Terengganu, \\ Kuala Terengganu, Malaysia \\ ${ }^{2}$ Institute of Oceanography and Maritime Studies, Kulliyyah of Science, International Islamic University Malaysia, \\ Kuantan, Malaysia \\ Email: *antonina@umt.edu.my
}

Received January 3,' 2013; revised February 5, 2013; accepted March 15, 2013

Copyright (c 2013 A. Nor Antonina et al. This is an open access article distributed under the Creative Commons Attribution License, which permits unrestricted use, distribution, and reproduction in any medium, provided the original work is properly cited.

\begin{abstract}
A study on the rare earth elements (REEs) of Redang Island marine sediments was conducted in August 2011 during the pre-monsoon season. Bottom sediments were collected from 27 sampling stations on board UMT Discovery II vessel using a Smith McIntyre grab and analyzed for rare earth elements (REEs) using inductively coupled plasma mass spectrometry (ICP-MS). Results showed that the REEs patterns in sediments reflected the source rock patterns with an overall order of abundance such as: light rare earth elements (LREE) > middle rare earth element (MREE) > high rare earth elements (HREE). The chondrite normalized patterns of REEs showed enrichment of LREEs over HREEs with La/Yb of 13.6 while the chondrite normalized value showed low $(\mathrm{Gd} / \mathrm{Yb})_{\mathrm{N}}$ ratios $(2.12)$ which was illustrated in the flat HREE pattern. The chondrite normalized REE patterns of sediments showed the enrichment of LREE and depletion of HREE. From our findings, REEs concentrations in the study area were found to be of geogenic origins and the distributions were not influenced by anthropogenic sources.
\end{abstract}

Keywords: Rare Earth Elements; Marine Sediments; Redang Island; Malaysia

\section{Introduction}

Geochemical reactions in the ocean sediments play a major role in maintaining and/or altering the chemical composition of surrounding waters. Several studies have explored the geochemistry and distribution of rare earth elements (REEs) in aquatic systems [1-7]. REEs have been observed to be a potential pollution tracer because of their strong binding capability with soil, low mobility, low natural backgrounds in soils, and non-toxic character [8]. REEs include the 15 lanthanide elements $(Z=57$ through 71) and yttrium $(Z=39)$. These exhibit identical physical and chemical properties making them useful probes of low temperature geochemical reactions [9].

The REE range from La-Sm is classified as light rare earth elements (LREE) and Gd-Lu is considered to be heavy rare earth elements (HREE). Comparison among REEs will facilitate in normalization of analyses to reference standards such as chondrite [8]. The use of this

\footnotetext{
${ }^{*}$ Corresponding author.
}

method eliminates the abundance variation between lanthanides of odd and even atomic number and allows determination of the extent of fractionation between the lanthanides, because such fractionation is not considered to have taken place during chondrite formation. The method is also useful because chondrites are thought to be compositionally similar to the original earth's mantle [10].

Previous works suggest that large scale removal of dissolved REEs, particularly light REEs, in the estuarine mixing zone tends to reduce the effective fluvial flux of REEs to the ocean and significantly affects the calculation of REEs in the ocean [2]. Despite its global significance as a useful sensor of magmatic processes in aquatic habitat, the distributions of REEs in the South China Sea adjacent to Peninsular Malaysia are poorly known [11]. The goal of this study was to determine the distribution of REEs in Redang Island waters, one of the tourism islands of Malaysia. 


\section{Materials and Methods}

Redang Island is located in the South China Sea off the East Coast of Peninsular Malaysia (Latitude $5^{\circ} 44^{\prime} \mathrm{N}$ $5^{\circ} 50^{\prime} \mathrm{N}$ and $\left.\mathrm{L} 102^{\circ} 59^{\prime} \mathrm{E}-103^{\circ} 5^{\prime} \mathrm{E}\right)$. It lies about $45 \mathrm{~km}$ north-northeast of Kuala Terengganu, the state capital of Terengganu and about $22 \mathrm{~km}$ off Tanjung Merang, the closest point on the mainland [12].

\subsection{Sampling}

Sediment samples from 27 marine sites surrounding Redang Island were taken using a Smith McIntyre Grab sampler from the RV Discovery II platform (Figure 1). Sediment samples were placed in plastic bags and brought back to the laboratory for analysis.

\subsection{Laboratory Analysis}

All apparatus such as spoon and plastic container used in collecting the sediment samples were submerged for at least 3 to 4 days with $\mathrm{HNO}_{3}$ to get rid of contamination. During the sampling, large shell fragments were removed from the sediment samples. Approximately 30 to 50 grams were put in an acid-cleaned petri dishes and then oven dried at a temperature of $50^{\circ} \mathrm{C}$. After oven drying for at least 3 to 4 days, or until constant weight has been attained, the samples were ground lightly in a mortar and a pestle to break up the particles. The dry sediments were then passed through a $63 \mu \mathrm{m}$ sieve which represented the composite sediment sample.

\subsection{Microwave Digestion}

One gram of the prepared composite sample was accurately weighed into acid-cleaned teflon beakers. A Milestone Ethos 1600 microwave digester was used to digest

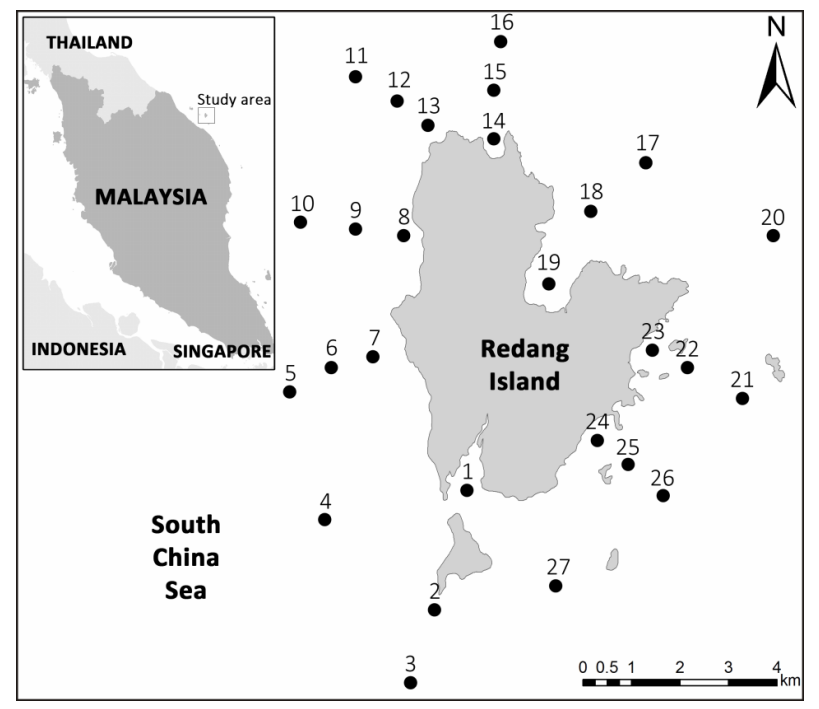

Figure 1. Map and location of sampling stations in the study area. the entire sample using Kulkarni et al. [13] procedure. 3 ml $\mathrm{HNO}_{3}$ solution and $0.3 \mathrm{ml} \mathrm{HF}$ solution were added to the samples and the temperature was set at $200^{\circ} \mathrm{C}$ at 200 psi pressure for 40 minutes. Then, the vessel was left to cool for 60 - 90 minutes. For dual-stage digestions, 5\% (m/v) $\mathrm{H}_{3} \mathrm{BO}_{3}$ was added to the vessel and heated at same microwave settings. After cooling, the digest was diluted with ultrapure water to a final volume of $50 \mathrm{ml}$ prior to ICP-MS detection for REEs. A certified reference material, estuarine sediment (NBS 1646a) from the National Institute of Standards and Technology (NIST) was digested in the same manner as Redang Island sediment samples and analyzed to determine the recovery levels and accuracy of metal analyses. The recoveries for all metals ranged between $78 \%$ - 93\% with slightly lower recoveries obtained Neodymium $(\mathrm{Nd})$.

\section{Results and Discussion}

The average mean values of detected concentrations of REEs in the sediments are presented in Table 1. Results show that the concentrations of REEs in sediments varied between 18.6 and $126.2 \mu \mathrm{g} / \mathrm{g}$ with an average value of $74.1 \mu \mathrm{g} / \mathrm{g}$.

The concentrations of the 14 REEs in sediments followed the order of $\mathrm{Ce}>\mathrm{La}>\mathrm{Nd}>\operatorname{Pr}>\mathrm{Sm}>$ Eu $>$ Gd $>$ Dy $>$ $\mathrm{Yb}>\mathrm{Er}>\mathrm{Lu}>\mathrm{Tb}>\mathrm{Ho}>\mathrm{Tm}$ which is relatively similar to the previous study in South China Sea reported by Bao and Li (1993) and mean REE values in oceanic crust proposed by Ronov et al. [14] (Table 2).

The distribution patterns of REEs in the study area are shown in Figure 2. From the isopleth map, it is clear that stations 11 to 13 have the highest concentrations of

Table 1. REEs concentrations in the study area $(\mu \mathrm{g} / \mathrm{g})$.

\begin{tabular}{cccc}
\hline Element & Minimum & Maximum & Mean \\
\hline Lanthanum (La) & 3.90 & 26.60 & 16.30 \\
Cerium (Ce) & 5.30 & 40.80 & 24.50 \\
Praseodymium (Pr) & 1.03 & 7.12 & 4.30 \\
Neodymium (Nd) & 3.14 & 21.10 & 12.80 \\
Samarium (Sm) & 1.02 & 9.12 & 4.20 \\
Europium (Eu) & 1.71 & 5.15 & 3.39 \\
Gadolinium (Gd) & 0.71 & 4.33 & 2.47 \\
Terbium (Tb) & 0.19 & 1.32 & 0.65 \\
Dysprosium (Dy) & 0.46 & 3.06 & 1.54 \\
Holmium (Ho) & 0.17 & 1.14 & 0.59 \\
Erbium (Er) & 0.28 & 1.98 & 1.04 \\
Thulium (Tm) & 0.12 & 0.70 & 0.42 \\
Ytterbium (Yb) & 0.32 & 2.18 & 1.20 \\
Lutetium (Lu) & 0.20 & 1.57 & 0.66 \\
Average REEs & 18.6 & 126.2 & 74.1 \\
\hline
\end{tabular}



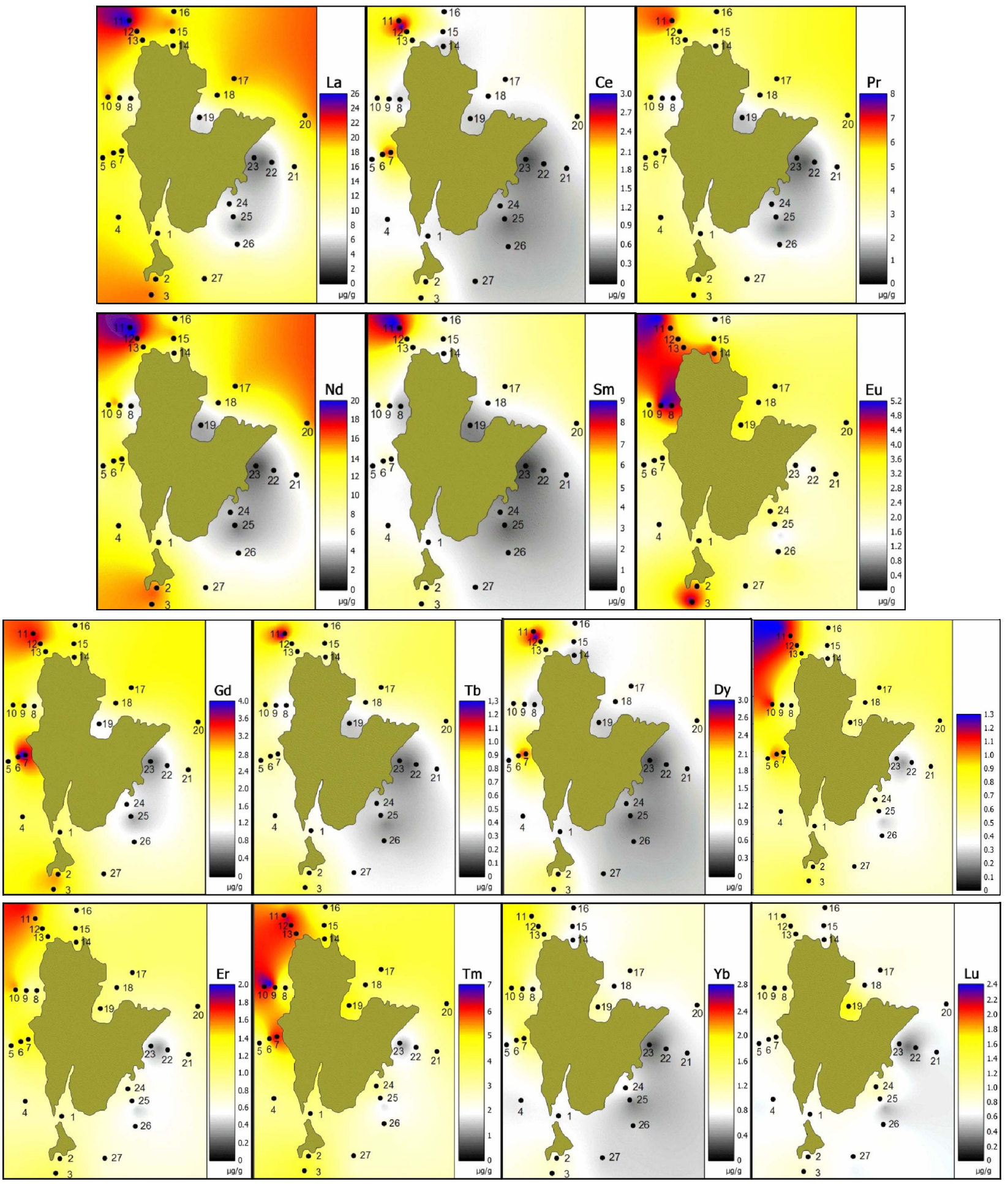

Figure 2. Distribution patterns of REE off Redang Island ( $\mu \mathrm{g} / \mathrm{g}$ dry weight).

selected REEs. These sampling stations are located near tourism spots for snorkeling and boating. However, the concentrations of REEs are still low compared to the oceanic crust values (Table 2).

It is very important to discuss what material is suitable for normalization of geochemical samples. The chondrite normalized REE patterns to the value of Anders and Grevesse [15] in sediment are shown in Figure 3. This fractionation is characterized by a significant enrichment in LREE over HREE. The chondrite-normalized REE 
Table 2. Comparisons of REEs concentrations $(\mu \mathrm{g} / \mathrm{g})$ in the South China Sea, oceanic crust and the study area.

\begin{tabular}{cccc}
\hline REE & $\begin{array}{c}\text { Redang Island } \\
\text { (Present study) }\end{array}$ & $\begin{array}{c}\text { South China Sea } \\
{[17]}\end{array}$ & $\begin{array}{c}\text { Oceanic crust } \\
{[14]}\end{array}$ \\
\hline $\mathrm{La}$ & 16.30 & 166.00 & 16.0 \\
$\mathrm{Ce}$ & 24.50 & 917.00 & 28.0 \\
$\mathrm{Pr}$ & 4.30 & 41.00 & 4.7 \\
$\mathrm{Nd}$ & 12.80 & 133.00 & 21.0 \\
$\mathrm{Sm}$ & 4.20 & 44.00 & 5.3 \\
$\mathrm{Eu}$ & 3.39 & 12.80 & 1.4 \\
$\mathrm{Gd}$ & 2.47 & 48.00 & 5.9 \\
$\mathrm{~Tb}$ & 0.65 & 9.74 & 0.9 \\
$\mathrm{Dy}$ & 1.54 & 53.00 & 4.9 \\
$\mathrm{Ho}$ & 0.59 & 7.30 & - \\
$\mathrm{Er}$ & 1.04 & 22.10 & 3.1 \\
$\mathrm{Tm}$ & 0.42 & 5.44 & - \\
$\mathrm{Yb}$ & 1.20 & 19.60 & 2.7 \\
$\mathrm{Lu}$ & 0.66 & 4.98 & - \\
\hline
\end{tabular}

pattern of marine sediment collected in the study area was similar to the results obtained by Khadijeh Saraee et al. [16] for the east coast of Peninsular Malaysia region.

The average of REEs concentration was observed to be $74.1 \mu \mathrm{g} / \mathrm{g}$ (Table 1). The table showed REEs patterns that are similar by having higher LREE concentrations, a positive Eu anomaly and lower in HREE concentrations (Figure 3). The REEs concentrations showed a slightly negative Ce anomaly which is an indicator of marine depositional environments [18]. The chondrite normalized REE patterns were similar to results obtained by Sultan and Shazili [11] in a similar study of Terengganu river basin sediments. The negative Ce anomaly was also partially due to early stage weathering which led to less pronounced REE fractionation. This finding corresponds well with those of Sultan and Shazili [11].

Higher REE ratios $(\mathrm{Ce} / \mathrm{La}, \mathrm{Gd} / \mathrm{Yb}$ and $\mathrm{La} / \mathrm{Yb})$ were observed at stations 4, 9, 11, 14, 17 and 20 (Table 3). The lowest ratios (Ce/La, Gd/Yb and La/Yb) were observed at station 19 (Table 3) which is one of the main tourism areas of Redang Island. This might be due to the location of the sampling area which was completely covered with shell fragments where the abundance of quartz and calcite as natural carbonate sediments at this site would tend to dilute the REE abundance.

Chondrite normalization showed high $(\mathrm{La} / \mathrm{Yb})_{\mathrm{N}}$ ratios (14.13) which reflect highly fractioned REE compositions. This is in agreement with the finding of Sultan and Shazili [11] of high $(\mathrm{La} / \mathrm{Yb})_{\mathrm{N}}$ ratios in both river sediments (18.8) and lake sediments (20.6) of the Terengganu river basin. However, Khadijeh Saraee et al. [16] found $\mathrm{La} / \mathrm{Yb}$ ratio values ranging from 7.4 to 16.7 in marine sediments of South China Sea which could be pre-monsoon

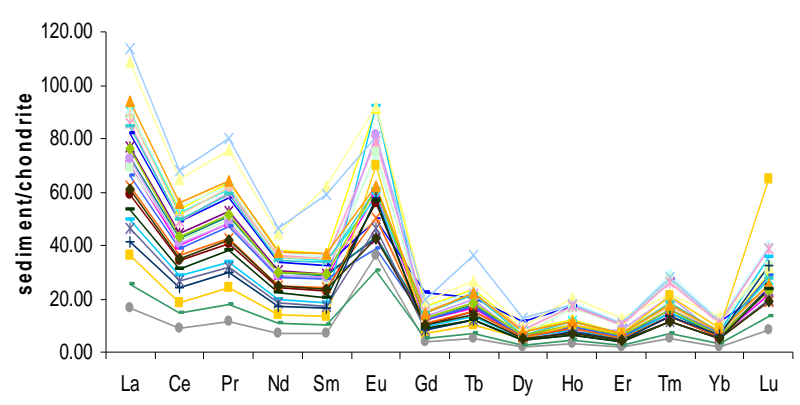

Figure 3. REE patterns in sediment normalized to the concentrations in chondrite in the study area.

Table 3. Ratios of REEs in sediments of Redang Island.

\begin{tabular}{|c|c|c|c|}
\hline Station & $\mathrm{Ce} / \mathrm{La}$ & $\mathbf{G d} / \mathbf{Y b}$ & $\mathbf{L a} / \mathbf{Y b}$ \\
\hline 1 & 1.48 & 2.50 & 17.39 \\
\hline 2 & 1.52 & 2.64 & 16.61 \\
\hline 3 & 1.48 & 2.52 & 17.46 \\
\hline 4 & 1.49 & 2.72 & 20.25 \\
\hline 5 & 1.51 & 2.13 & 14.36 \\
\hline 6 & 1.50 & 2.40 & 16.83 \\
\hline 7 & 1.54 & 2.28 & 10.08 \\
\hline 8 & 1.48 & 1.54 & 9.63 \\
\hline 9 & 1.55 & 1.70 & 11.04 \\
\hline 10 & 1.54 & 1.32 & 8.63 \\
\hline 11 & 1.52 & 1.70 & 11.70 \\
\hline 12 & 1.54 & 2.07 & 14.15 \\
\hline 13 & 1.48 & 1.68 & 11.20 \\
\hline 14 & 1.45 & 2.90 & 18.48 \\
\hline 15 & 1.48 & 2.53 & 17.69 \\
\hline 16 & 1.50 & 2.03 & 13.56 \\
\hline 17 & 1.51 & 2.31 & 15.75 \\
\hline 18 & 1.46 & 2.41 & 16.88 \\
\hline 19 & 1.31 & 0.97 & 5.73 \\
\hline 20 & 1.53 & 2.39 & 18.36 \\
\hline 21 & 1.48 & 2.37 & 16.28 \\
\hline 22 & 1.48 & 2.03 & 13.71 \\
\hline 23 & 1.36 & 2.22 & 12.19 \\
\hline 24 & 1.51 & 1.51 & 9.15 \\
\hline 25 & 1.47 & 1.88 & 12.02 \\
\hline 26 & 1.51 & 2.15 & 15.18 \\
\hline 27 & 1.48 & 2.34 & 17.28 \\
\hline Mean \pm S.D & $1.49 \pm 0.05$ & $2.12 \pm 0.46$ & $14.13 \pm 3.63$ \\
\hline
\end{tabular}

explained by an increase in the complexation of REE with seawater carbon ligands with increasing of the atomic number. $(\mathrm{Gd} / \mathrm{Yb})_{\mathrm{N}}$ ratio was calculated to investigate the relative depletion of HREE. The chondrite normalized value shows low $(\mathrm{Gd} / \mathrm{Yb})_{\mathrm{N}}$ ratios (2.12) which is illustrated by the flat HREE pattern (Figure 3). The Ce/La 
ratio in Redang Island sediments was 1.49 . This Ce/La ratio was comparable to findings by Khadijeh Saraee et al. [16] who observed Ce/La ratio of 1.3 for east coast Peninsular Malaysia core sediments. This might be due to an increasing amount of carbonate, biogenic and terrigenous components in the sediment sample. The abundance of carbonate in the sediments of Redang Island supports the finding of the positive $\mathrm{Ce} / \mathrm{La}$ ratios for its sediments.

The proportion enrichment of REE in sediments remained similar with increasing atomic number. HREE are more soluble and more complex than middle or light REE and are more strongly absorbed on most substrates [19]. This might explain the enrichment patterns of LREE in Redang Island sediments.

\section{Conclusion}

The distribution patterns of REEs show that concentrations of 14 REEs studied were low compared to the earth crust values. The chondrite-normalized patterns suggested LREEs and HREEs fractionation in the marine environment resulting in higher LREEs and less HREEs absorbed in the sediment. The REE patterns in sediments had an overall abundance order of LREE > MREE > HREE. The chondrite normalized REE patterns in the sediments of Redang Island corresponded well with previous results from the Terengganu river basin. The REEs were significantly $(\mathrm{P}<0.01)$ correlated with $\mathrm{Al}$ indicating that REE concentrations in the study area were of geogenic origins and not influenced by anthropogenic sources.

\section{REFERENCES}

[1] H. Elderfield, R. Upstill-Goddard and E. R. Sholkovitz, "The Rare Earth Elements in Rivers, Estuaries and Coastal Seas and Their Significance to the Composition of Ocean Waters," Geochimica et Cosmochimica Acta, Vol. 54, No. 4, 1990, pp. 971-991. doi:10.1016/0016-7037(90)90432-K

[2] E. R. Sholkovitz, "Chemical Evolution of Rare Earth Elements: Fractionation between Colloidal and Solution Phases of Filtered River Water," Earth and Planetary Science Letter, Vol. 114, No. 1, 1992, pp. 77-84. doi:10.1016/0012-821X(92)90152-L

[3] D. Rousseau D. B. Dupré, J. Gaillardet and C. J. Allègre, "Major and Trace Elements of River-Borne Material: The Congo Basin," Geochimica et Cosmochimica Acta, Vol. 60, No. 8, 1996, pp. 1301-1321. doi:10.1016/0016-7037(96)00043-9

[4] R. Ramesh, A. L. Ramanathan, S. Ramesh, R. Purvaja and V. Subramanian, "Distribution of Rare Earth Elements and Heavy Metals in the Surficial Sediments of the Himalayan River System,” Geochemical Journal, Vol. 34, 2000, pp. 295-319. doi:10.2343/geochemj.34.295

[5] Y. Nozaki, D. Lerche, D. S. Alibo and A. Snidvongs,
“The Estuarine Geochemistry of Rare Earth Elements and Indium in the Chao Phraya River, Thailand," Geochimica et Cosmochimica Acta, Vol. 64, No. 23, 2000, pp. 39833994. doi:10.1016/S0016-7037(00)00473-7

[6] P. Singh and V. Rajamani, "REE Geochemistry of Recent Clastic Sediments from the Kaveri Floodplains, Southern India: Implication to Source Area Weathering and Sedimentary Processes," Geochimica et Cosmochimica Acta, Vol. 65, 2001, pp. 3093-3108. doi:10.1016/S0016-7037(01)00636-6

[7] A. M. Shiller, "Seasonality of Dissolved Rare Earth Elements in the Lower Mississippi River," Geochemistry, Geophysics and Geosystems, Vol. 3, No. 11, 2002, pp. 1068-1082. doi:10.1029/2002GC000372

[8] M. A. Kimoto, X. C. Nearing, D. Zhang and M. Powell, "Applicability of Rare Earth Element Oxides as a Sediment Tracer for Coarse-Textured Soils,” Catena, Vol. 65, No. 3, 2006, pp. 214-221. doi:10.1016/j.catena.2005.10.002

[9] A. P. Jones, F. Wall and C. T. Williams, "Rare Earth Minerals Chemistry, Origin and Ore Deposits. Series: The Mineralogical Society Series,” Vol. 7, Springer Publisher, 1996.

[10] Z. L. Song, C. Q. Liu, G. L. Han, Z. L. Wang, Z. Z. Zhu and C. Yang, "Enrichment and Release of Rare Earth Elements during Weathering of Sedimentary Rocks in Wujiang Catchments, Southwest China,” Journal of Rare Earths, Vol. 24, No. 4, 2006, pp. 491-496. doi:10.1016/S1002-0721(06)60149-X

[11] K. Sultan and N. A. M. Shazili, "Rare Earth Elements in Tropical Surface Water, Soil and Sediments of the Terengganu River Basin, Malaysia,” Journal of Rare Earths, Vol. 27, No. 6, 2009, pp. 1072-1078. doi:10.1016/S1002-0721(08)60391-9

[12] T. T. Khoo, B. S. Yaw, T. Kimura and J. H. Kim, “Geology and Paleontology of the Redang Islands, Terengganu, Peninsular Malaysia,” Journal of Southeast Asian Earth Sciences, Vol. 2, No. 3-4, 1988, pp. 123-130. doi:10.1016/0743-9547(88)90023-2

[13] P. Kulkarni, S. Chellam, J. B. Flanagan and R. K. M. Jayanty, "Microwave Digestion: ICPMS for Elemental Analysis in Ambient Airbone Fine Particulate Matter: Rare Earth Elements and Validation Using a Filter Borne Fine Particle Certified Reference Material,” Analytica Chimica Acta, Vol. 599, No. 2, 2007, pp. 170-176. doi:10.1016/j.aca.2007.08.014

[14] A. B. Ronov, Y. A. Balashov and Y. P. Girin, "Regularities of Rare Earth Element Distribution in the Sedimentary Shell and in the Crust of the Earth," Sedimentology, Vol. 21, 1974, pp. 171-193. doi:10.1111/j.1365-3091.1974.tb02055.x

[15] E. Anders and N. Grevesse, "Abundances of the Elements: Meteoritic and Solar,” Geochimica et Cosmochimica Acta, Vol. 53, No. 1, 1989, pp. 197-214. doi:10.1016/0016-7037(89)90286-X.

[16] R. I. Khadijeh Saraee, S. B. Elias, A. K. Wood and A. M. Reza, "Rare Earth Elements Distribution in Marine Sediments of Malaysia Coasts," Journal of Rare Earths, Vol. 27, No. 6, 2009, pp. 1066-1077. 


\section{doi:10.1016/S1002-0721(08)60390-7}

[17] G. Bao and Q. Li, “Geochemistry of Rare Earth Elements in Ferromanganese Nodules (Crusts) of the South China Sea," Oceanologia et Limnologia Sinica, Vol. 24, No. 3, 1993, pp. 304-309.

[18] R. W. Murray, T. Buchholtz, M. R. Brink, D. L. Jones, D. C. Gerlach and G. P. Russ, "Rare Earth Elements as Indi- cators of Different Marine Depositional Environments in Chert and Shale,” Geology, Vol. 18, 1990, pp. 268-272.

[19] R. H. Byrne and K. H. Kim, "Rare Earth Precipitation and Co-Precipitation Behavior: The Limiting Role of $\mathrm{PO}_{4}^{-3}$ on Dissolved Rare Earth Concentrations in Seawater," Geochimica Cosmochimica Acta, Vol. 57, No. 3, 1993, pp. 519-526. doi:10.1016/0016-7037(93)90364-3 